\title{
Validation of FeSiMg Alloy Production Model for the Experimental Process
}

\author{
Saeed Ghali, Mamdouh Eissa, and Hoda El-Faramawy \\ Steel Technology Department, Central Metallurgical Research \& Development Institute (CMRDI), Helwan 11421, Egypt \\ Correspondence should be addressed to Saeed Ghali, a3708052@yahoo.com
}

Received 24 August 2011; Accepted 14 November 2011

Academic Editor: Brij Kumar Dhindaw

Copyright () 2012 Saeed Ghali et al. This is an open access article distributed under the Creative Commons Attribution License, which permits unrestricted use, distribution, and reproduction in any medium, provided the original work is properly cited.

This paper investigates the effect of limestone, bauxite, fluorspar, and quartzite additions on the magnesium recovery in FeSiMg production from dolomite. Also, it illustrates the validation of the previous designed model. According to the model, magnesium content in the product alloy is calculated by the equation $[\mathrm{Mg}]=\left(\mathrm{MgO}_{0}\right)\left[\mathrm{Si}_{0}\right]\left[e^{K t\left[\left(\mathrm{MgO}_{0}\right)-\left[\mathrm{Si}_{0}\right]\right]}-1\right] /\left(\left(\mathrm{MgO}_{0}\right)\left[e^{K t\left[\left(\mathrm{MgO}_{0}\right)-\left[\mathrm{Si}_{0}\right]\right]}\right]-\right.$ $\left.\left[\mathrm{Si}_{0}\right]\right)$, where $[\mathrm{Mg}]$ is the concentration of magnesium metal in ferrosilicon magnesium alloy in $\mathrm{mol} / \mathrm{L},\left[\mathrm{Si}_{0}\right]$ and $\left(\mathrm{MgO}_{0}\right)$ are the initial concentrations of silicon and magnesium oxide in charge in $\mathrm{mol} / \mathrm{L}, t$ is the time in seconds, and $K$ is the reaction rate constant $\left(3.26588 \times 10^{-7} \mathrm{LSec}^{-1} \mathrm{~mol}^{-1}\right)$. The results of the production process are compared with the model results. The deviation between the actual and predicted magnesium content decreases as fluorspar, limestone, and quartzite increase up to $12.8 \mathrm{wt} . \%, 8 \mathrm{wt} . \%$, and $8 \mathrm{wt} . \%$, respectively, with increase in the amount of the additives, the magnesium content in the produced alloy becomes far from the predicted values. It was found also that the addition of bauxite increases the gap between the actual and predicted values of magnesium content. It was found that the deviation of the actual magnesium content from the predicted depends mainly on the viscosity of the slag.

\section{Introduction}

Ferrosilicon magnesium alloys are used to produce all types of ductile cast iron. It is added to the molten iron for producing a structure containing graphite in nodular or spheroidal form [1]. This form minimizes the embrittlement effect of graphite on the metal matrix with the result of producing cast iron with better machinability, toughness, and tensile properties. Ferrosilicon magnesium consists mainly of magnesium silicides combined with the silicides of iron, calcium and rare earth metals. The silicothermic process is one of the most attractive techniques for producing FeSiMg alloy. This is attributed to much lower working temperature compared with carbothermic process. Also, it is of much lower cost compared with the alumino-thermic process. The oldest trials to reduce magnesium oxide with silicon were carried out by Kubaschewski and Evans [2] and Misra et al. [3]. Their results $[2,3]$ showed a low recovery of magnesium under this working conditions. They attributed this phenomenon to the formation of magnesium orthosilicate. Misra et al. [4] have also found that silicothermic reduction of pure magnesium oxide results in a poor magnesium recovery, due to the fact that a part of the magnesium oxide combines with the silica. Recovery of magnesium can be improved by carrying out the reduction of magnesium oxide in the presence of a metallic oxide that can form silicates more stable than magnesium orthosilicate. According to the thermodynamic data, lime can be considered as a suitable additive for improving the reduction process of magnesium oxide due to the fact that its silicate is more easily formed than magnesium silicate $[3,5,6]$. Thus, better recovery is expected when a mixture of lime and magnesite was used. Calcinated dolomite seems to be a suitable cheap raw material for the production of ferrosilicon magnesium alloy. Using silicothermic reduction process to produce magnesium-bearing alloys, which can be carried out in submerged arc furnace.

At temperature range $1650-1750^{\circ} \mathrm{C}$ [7-9], silicon will react with the constituents of charge that have lower affinity to oxygen than silicon to form $\mathrm{SiO}_{2}$. Then, $\mathrm{SiO}_{2}$ will react with $\mathrm{CaO}$ and $\mathrm{MgO}$ to form low-temperature molten 
silicates. The product of calcium silicate and magnesium silicate will react with molten silicon metal according to the reactions

$$
\begin{gathered}
2\left[\mathrm{CaO} \cdot \mathrm{SiO}_{2(\mathrm{~L})}\right]+5 \mathrm{Si}_{(\mathrm{L})} \longrightarrow 2 \mathrm{CaSi}_{2}+3 \mathrm{SiO}_{2} \\
\Delta G=-8515.447+1.5411 \mathrm{~T}, \\
2\left[\mathrm{MgO} \cdot \mathrm{SiO}_{2(\mathrm{~L})}\right]+2 \mathrm{Si}_{(\mathrm{L})} \longrightarrow \mathrm{Mg}_{2} \mathrm{Si}+3 \mathrm{SiO}_{2} \\
\Delta G=-6711.941+1.1478 \mathrm{~T} .
\end{gathered}
$$

The above reactions followed by the fact that calcium oxide has greater affinity to silica, and, therefore, it form more stable suitable silicate than magnesium oxide $[10,11]$ :

$$
\begin{aligned}
& 2\left[\mathrm{MgO} \cdot \mathrm{CaO} \cdot \mathrm{SiO}_{2(\mathrm{~L})}\right]+2 \mathrm{Si}_{(\mathrm{L})} \\
& \quad \longrightarrow \mathrm{Mg}_{2} \mathrm{Si}+\mathrm{SiO}_{2}+2\left[\mathrm{CaO} \cdot \mathrm{SiO}_{2}\right] \\
& \Delta G=-6148.5398+1.031 T .
\end{aligned}
$$

\section{Aim and Scope}

This paper aims at investigating the influence of bauxite, quartzite, limestone, and fluorspar on the extent of deviation of magnesium content from the predicted values by using the suggested model by Ghali [12]. This model used the following equation to calculate the magnesium content in the produced FeSiMg alloy:

$$
[\mathrm{Mg}]=\frac{\left(\mathrm{MgO}_{0}\right)\left[\mathrm{Si}_{0}\right]\left[e^{K t\left[\left(\mathrm{MgO}_{0}\right)-\left[\mathrm{Si}_{0}\right]\right]}-1\right]}{\left(\mathrm{MgO}_{0}\right)\left[e^{K t\left[\left(\mathrm{MgO}_{0}\right)-\left[\mathrm{Si}_{0}\right]\right]}\right]-\left[\mathrm{Si}_{0}\right]},
$$

where $[\mathrm{Mg}]$ is the concentration of magnesium metal in ferrosilicon magnesium alloy in $\mathrm{mol} / \mathrm{L},\left[\mathrm{Si}_{0}\right]$ and $\left(\mathrm{MgO}_{0}\right)$ are the initial contents of silicon and magnesium oxide in charge, respectively, in mol/L, $t$ the time in second, and $K$ the reaction rate constant $3.26588 \times 10^{-7} \mathrm{~L} \mathrm{Sec}^{-1} \mathrm{~mol}^{-1}$.

\section{Experimental}

The FeSiMg production data [13], which are produced by the experimental melting in a submerged arc furnace, are given in Tables 1 and 2. The molar concentrations of $\mathrm{SiO}_{2}, \mathrm{Al}_{2} \mathrm{O}_{3}$, $\mathrm{CaF}_{2}$, and $\mathrm{CaO}$ were calculated.

The data [13] from the previous study was considered as the main source for the evaluation of the new model. The different production parameters were considered and correlated to predict the different relations and dependences in the product process.

The amount and effect of different additives on the recovery of magnesium and composition of the product alloy were considered. Magnesium content is measured by using wet analysis method [14].

\section{Results and Discussion}

The data used in this investigation were obtained from ElFaramawy et al. [13] and Ghali [12]. The effect of fluxes (limestone, fluorspar, quartzite, and bauxite) on magnesium content and recovery in FeSiMg production process was investigated. The differences between the predicted values, by applying Ghali model [12], and the actual magnesium content and recovery in the FeSiMg alloy produced by metallothermic process using silicon as a reducing material [13] were considered. The results of four series of bench scale experiments having constant amount of dolomite with various weight percentages of limestone, quartzite, fluorspar, and bauxite, respectively (Table 1) were selected as the base for theoretical calculation.

Figure 1 shows the influence of weight ratio limestone/ dolomite on the difference between the predicted and actual magnesium content. It indicates that the difference decreases by increasing limestone/dolomite mass content ratio up to 8 wt.\%. Further increase of limestone wt.\% results increases the difference between predicted and actual magnesium mass content. This figure also shows that at optimum limestone mass content the predicted values of magnesium mass content are in good agreement with the actual values. This could be attributed to two opposing effects. The first one is the effect of increasing $\mathrm{CaO}$ content in $\mathrm{SiO}_{2}$-rich slag leading to the formation of $2 \mathrm{CaO} \cdot \mathrm{SiO}_{2}, 3 \mathrm{CaO} \cdot \mathrm{SiO}_{2}$, and $\mathrm{CaO} \cdot \mathrm{SiO}_{2}[6,15-19]$. According to the thermodynamic data free energy of formation of pure crystalline silicate from their component oxides as given in (5) and (6) [9], these compounds are formed first and are very stable leading to free $\mathrm{MgO}$ to be reduced

$$
\begin{gathered}
\mathrm{CaO}+\mathrm{SiO}_{2}=\mathrm{CaO} \cdot \mathrm{SiO}_{2}, \\
\Delta G(\mathrm{KJ} / \mathrm{mol})=-2368.75+0.392 \mathrm{~T}, \\
\mathrm{MgO}+\mathrm{SiO}_{2}=\mathrm{MgO} \cdot \mathrm{SiO}_{2}, \\
\Delta G(\mathrm{KJ} / \mathrm{mol})=-2312.78+0.308 T .
\end{gathered}
$$

The other one is the negative effect of increasing the content of these high melting compounds $3 \mathrm{CaO} \cdot \mathrm{SiO}_{2}$, $2 \mathrm{CaO} \cdot \mathrm{SiO}_{2}$, and $\mathrm{CaO} \cdot \mathrm{SiO}_{2}$ with respective melting temperatures of $2070^{\circ} \mathrm{C}, 2130^{\circ} \mathrm{C}$, and $1564^{\circ} \mathrm{C}$, resulting in increasing the slag viscosity. Furthermore, the presence of $\mathrm{CO}_{2}$ gas, from the decomposition of limestone, leads to more oxidation of magnesium. The outcome of these two opposite effects leads to an optimum value. In other words, the increase of the $\mathrm{CaO}$ content in the charge is accompanied by an increase in the activity of $\mathrm{MgO}$ in the slag. This is due to liberation of $\mathrm{MgO}$ from $\mathrm{MgO} \cdot \mathrm{SiO}_{2}$ and formation of $\mathrm{CaO} \cdot \mathrm{SiO}_{2}$ as shown in (5) and (6). This leads to increasing magnesium recovery and hence the gap between the predicted and actual magnesium content decreases. Further increase of limestone content is accompanied by an increase in slag viscosity. This is due to the formation of $2 \mathrm{CaO} \cdot \mathrm{SiO}_{2}$, and $3 \mathrm{CaO} \cdot \mathrm{SiO}_{2}$ which have high melting points $2070^{\circ} \mathrm{C}$ and $2130^{\circ} \mathrm{C}$, respectively. This deteriorates the diffusion of reactants to the reaction zone. Thus increasing the difference between the predicted and actual magnesium content in the product alloy.

The effect of fluorspar content in the charge on the deviation of the actual magnesium content, given in Table 1 [13], from the predicted values using Ghali model [12] is illustrated in Figure 2. From this figure it is clear that the difference between the predicted magnesium contents 
TABLE 1: Materials balance of the experimental heats.

\begin{tabular}{|c|c|c|c|c|c|c|c|c|c|c|c|}
\hline \multirow[b]{2}{*}{ Heat no. } & \multicolumn{8}{|c|}{ Input, gm } & \multicolumn{2}{|c|}{ Output } & \multirow{2}{*}{$\begin{array}{c}\text { Predicted } \\
\text { Mg mass } \\
\text { content in } \\
\%\end{array}$} \\
\hline & Dolomite & $\mathrm{FeSi}$ & Fluorspar & Limestone & $\mathrm{Al}$ & Quartzite & Bauxite & $\mathrm{CeSO}_{4}$ & $\begin{array}{c}\text { Metal } \\
\text { mass }\end{array}$ & $\begin{array}{c}\text { Mg mass } \\
\text { content } \\
\text { in } \%,\end{array}$ & \\
\hline 1 & 1250 & 750 & 100 & 50 & & & & 25 & 725 & 2.25 & 4.38 \\
\hline 2 & 1250 & 750 & 100 & 70 & & & & 25 & 590 & 2.86 & 5.30 \\
\hline 3 & 1250 & 750 & 100 & 100 & & & & 25 & 550 & 4.1 & 5.54 \\
\hline 4 & 1250 & 750 & 100 & 130 & & & & 25 & 430 & 2.0 & 6.90 \\
\hline 5 & 1250 & 750 & 100 & 150 & & & & 25 & 441.5 & 1.3 & 6.61 \\
\hline 6 & 1250 & 600 & 160 & & 50 & 50 & & 25 & 480 & 1.7 & 5.48 \\
\hline 7 & 1250 & 600 & 160 & & 50 & 75 & & 25 & 558 & 1.8 & 4.60 \\
\hline 8 & 1250 & 600 & 160 & & 50 & 100 & & 25 & 622 & 3.2 & 4.04 \\
\hline 9 & 1250 & 600 & 160 & & 50 & 150 & & 25 & 813 & 1.6 & 2.96 \\
\hline 10 & 1250 & 600 & 40 & & 50 & & & 25 & 750 & 1.76 & 4.11 \\
\hline 11 & 1250 & 600 & 80 & & 50 & & & 25 & 489 & 3.5 & 6.06 \\
\hline 12 & 1250 & 600 & 120 & & 50 & & & 25 & 550 & 3.5 & 5.19 \\
\hline 13 & 1250 & 600 & 160 & & 50 & & & 25 & 575 & 4.24 & 4.78 \\
\hline 14 & 1250 & 600 & 200 & & 50 & & & 25 & 595 & 3.25 & 4.45 \\
\hline 15 & 1250 & 600 & 400 & & 50 & & & 25 & 550 & 3.25 & 4.05 \\
\hline 16 & 1250 & 950 & 160 & & & & 50 & 25 & 983 & 2.45 & 3.19 \\
\hline 17 & 1250 & 950 & 160 & & & & 100 & 25 & 828 & 2.84 & 3.67 \\
\hline 18 & 1250 & 950 & 160 & & & & 150 & 25 & 731 & 3.05 & 3.99 \\
\hline 19 & 1250 & 950 & 160 & & & & 200 & 25 & 805 & 2.52 & 3.50 \\
\hline 20 & 1250 & 950 & 160 & & & & 250 & 25 & 750 & 2.63 & 3.62 \\
\hline
\end{tabular}

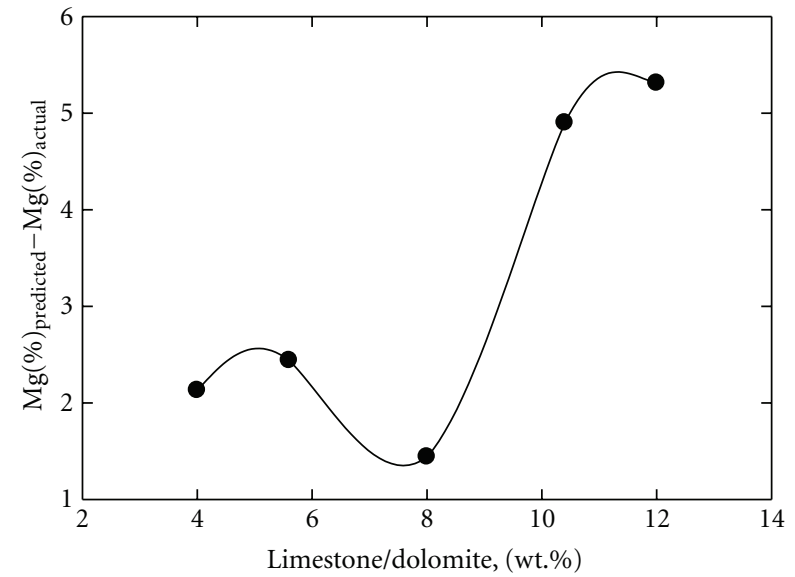

FIGURE 1: Effect of limestone/dolomite weight $\%$ on the gap between the predicted and actual magnesium content.

and actual values decreases by increasing fluorspar/dolomite weight ratios in the charge up to 12.8 weight content in $\%$. Further increase in the fluorspar percentage leads to a large gap between predicted and actual values of magnesium content.

Figure 3 shows the effect of quartzite/dolomite weight ratios on the deviation of the actual magnesium content from the predicted values. It is clear that the gap between the actual and predicted magnesium content decreases by increasing

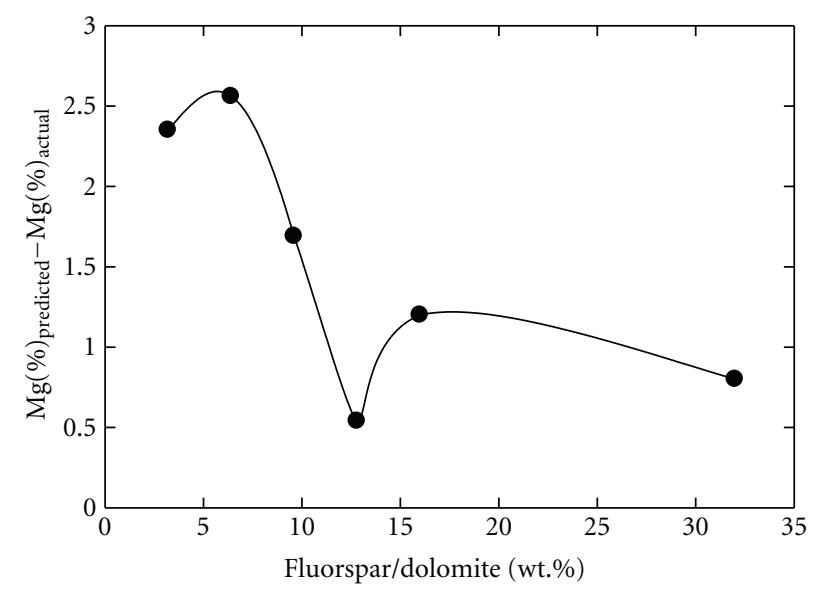

Figure 2: Influence of fluorspar/dolomite weight $\%$ on the difference between the predicted and actual magnesium content.

quartzite/dolomite weight ratio up to 8 weight content in \%. Further increase in quartzite/dolomite weight ratio leads to increasing the difference between the actual and predicted magnesium content.

On the other hand, increasing the bauxite content in the charge is accompanied by higher-degree deviation of the actual magnesium content from the predicted values as given in Figure 4. 
TABLE 2: Chemical composition of the charge constituents.

\begin{tabular}{|c|c|c|c|c|c|c|c|c|}
\hline \multirow[b]{2}{*}{ Constituents } & \multicolumn{8}{|c|}{ Chemical composition, mass content in \% } \\
\hline & $\begin{array}{l}\text { Calcinated } \\
\text { dolomite }\end{array}$ & Fluorspar & $\begin{array}{l}\text { Rare earth } \\
\text { metals }\end{array}$ & Limestone & Quartzite & Bauxite & $\mathrm{FeSi}$ & $\mathrm{Al}$ \\
\hline $\mathrm{SiO}_{2}$ & 1.4 & 12.6 & & 3.88 & 95 & 6.43 & & \\
\hline $\mathrm{Fe}_{2} \mathrm{O}_{3}$ & 1.45 & 0.35 & & 0.5 & 0.2 & & & \\
\hline $\mathrm{CaO}$ & 62.4 & & 1 & 51.78 & & & & \\
\hline $\mathrm{MgO}$ & 33.6 & & 1 & 0.6 & 0.3 & & & \\
\hline L.O.I. at $1000^{\circ} \mathrm{C}$ & 0.43 & & & 41.3 & & & & \\
\hline $\mathrm{Al}_{2} \mathrm{O}_{3}$ & 1 & 2.4 & & 0.8 & 2.5 & 85 & & \\
\hline $\mathrm{Na}_{2} \mathrm{O}$ & & & 1 & 1.64 & & & & \\
\hline $\mathrm{K}_{2} \mathrm{O}$ & & & & 0.35 & & & & \\
\hline $\mathrm{CaF}_{2}$ & & 82 & & & & & & \\
\hline $\mathrm{CaCO}_{3}$ & & 2.2 & & & & & & \\
\hline $\mathrm{P}_{2} \mathrm{O}_{3}$ & & & 0.01 & & & & & \\
\hline $\mathrm{CeO}_{2} / \mathrm{ReO}$ & & & 45 & & & & & \\
\hline $\mathrm{Fe}$ & & & 0.005 & 0.34 & 0.14 & & 23.3 & \\
\hline $\mathrm{Pb}$ & & & 0.001 & & & & & \\
\hline $\mathrm{P}_{2} \mathrm{O}_{5}$ & & 0.001 & & & & & & \\
\hline $\mathrm{SO}_{3}$ & & & 0.03 & & & & & \\
\hline $\mathrm{FeO}$ & & & & & & 1.8 & & \\
\hline C & & & & & & & 0.09 & \\
\hline S & & & & & & & 0.003 & \\
\hline $\mathrm{P}$ & & & & & & & 0.031 & \\
\hline $\mathrm{Al}$ & & & & & & & 1.41 & 99 \\
\hline $\mathrm{Ca}$ & & & & & & & 0.31 & \\
\hline $\mathrm{Si}$ & & & & & & & 74.8 & \\
\hline
\end{tabular}

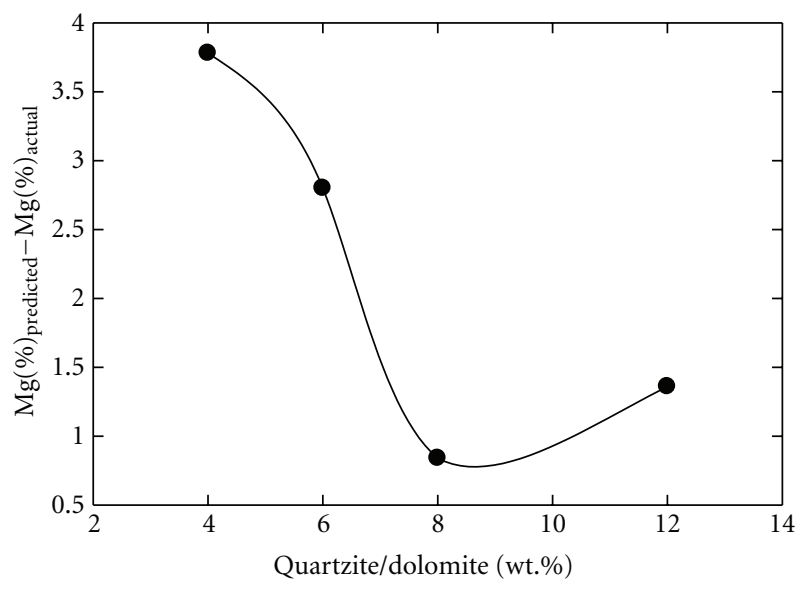

FIGURE 3: Effect of quartzite/dolomite weight\% on the difference between the predicted and actual magnesium content.

Reduction of dolomite by ferrosilicon takes place according to the following sequence: (1) the diffusion of $\mathrm{MgO}$ and $\mathrm{CaO}$ through the slag layer to the slag/metal interface, (2) chemical reaction between the reactants at the slag/metal interface, (3) the transformation of the metal droplets through slag/metal interface to the molten metal,

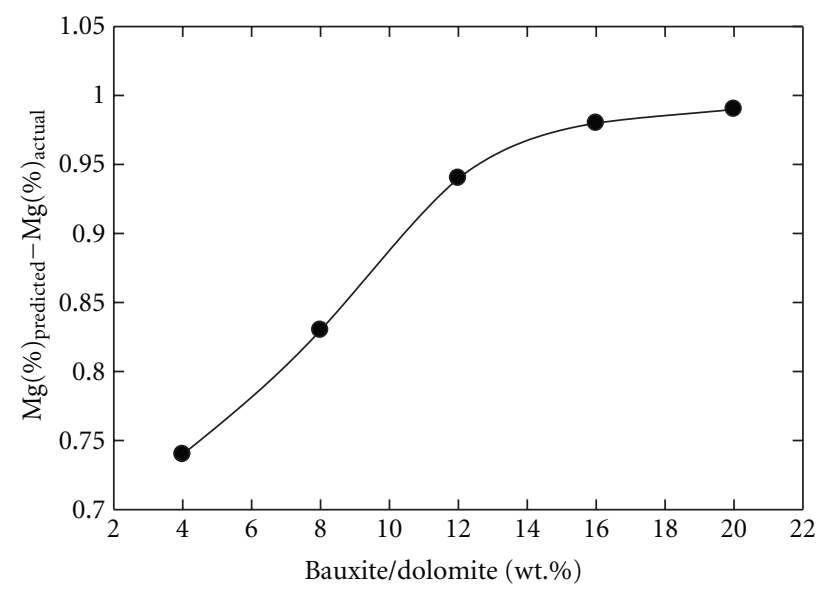

FIGURE 4: Effect of bauxite/dolomite weight $\%$ on the difference between the predicted and actual magnesium content.

(4) diffusion of non-metallic products of reaction through slag/metal interface to the slag layer. The diffusion rate of either the reactants or the products through the slag layer is controlled by the physical properties [20] of the molten slag. So, it is expected that the magnesium content will effectively be influenced by slag viscosity. Increasing viscosity of slag 
obstructs the diffusion of reactants and products to and from the reaction zone. Therefore, lower degree of deviation of actual magnesium content from the predicted one-as given in Figure 2-can be a result of increasing the fluorspar content. This phenomenon could be attributed to an increase of the slag fluidity due to high fluorspar content, which results in a higher rate of metallic droplets diffusion. On the other hand, addition of more fluorides to silicate slag results in evolution of silicon tetra fluoride $\left(\mathrm{SiF}_{4}\right)$ vapour [21]. Also, there is a diffusion constant of silicon between metal and slag at a given temperature.

Therefore, as the slag is saturated with $\mathrm{SiO}_{2}$, the silicon content in the alloy increases also leading to lower deviation in magnesium content between the actual and predicted values as illustrated in Figure 3. With further addition of quartzite, the excess $\mathrm{SiO}_{2}$ tends to form a less stable compound such as $\mathrm{Ca}_{3} \mathrm{Mg}\left(\mathrm{SiO}_{2}\right)$ [22, 23]. This compound is dissociated to $\mathrm{Ca}_{2} \mathrm{SiO}_{4}$ with a high melting point leading to more viscous slag.

The obtained results also showed the negative effect of bauxite addition on the deviation of the actual magnesium content from the predicted values, which could be attributed to the higher viscosity of high alumina slag [24-28].

Figure 4 shows the effect of bauxite (alumina content) on the magnesium content and the difference between the predicted and actual magnesium content. It is clear that the difference between the predicted $\mathrm{Mg}$ mass content in $\%$ and the actual $\mathrm{Mg}$ mass content in \% increases as the alumina increase. This behavior can be attributed to the effect of $\mathrm{Al}_{2} \mathrm{O}_{3}$ on the viscosity of slag. As $\mathrm{Al}_{2} \mathrm{O}_{3}$ content increases, the slag viscosity becomes higher. The high viscosity has negative significant effect on the diffusion rate. The diffusion rates of either the reactants or products through the slag layer decrease due to the effect of alumina. This leads to decrease in magnesium recovery and hence the gap between the predicted and actual magnesium content increases [13].

\section{Conclusions}

The following conclusions can be made.

(i) The deviation between the actual and predicted magnesium content decreases as the magnesium content in the produced alloy increases.

(ii) The highest magnesium content can be obtained using weight $\%$ of limestone/dolomite, quartzite/ dolomite and fluorspar/dolomite 8,8 , and 12.8 , respectively. This is in good agreement with the theoretically predicted values.

(iii) The addition of bauxite decreases the magnesium recovery due to high viscosity.

(iv) The physical properties, mainly the viscosity of the molten charge, play a significant role in the reduction process during the production of ferrosilicon magnesium alloy from dolomite.

\section{Acknowledgments}

M. Eissa is the head of the Steel Technology Department, Central Metallurgical Research \& Development Institute (CMRDI), Egypt. S. Ghali is a researcher at the Steel Technology Department, Central Metallurgical Research \& Development Institute (CMRDI), Egypt. H. El-Faramawy is a professor at the Steel Technology Department, Central Metallurgical Research \& Development Institute (CMRDI), Egypt.

\section{References}

[1] C. Labrecque and M. Gagne, "Review ductile iron: fifty years of continuous development," Canadian Metalurgical Quarterty, vol. 37, no. 5, pp. 343-378, 1998.

[2] O. Kubaschewski and E. L. Evans, Metallugical thermochemistry, Pergamon Press, London, UK, 1958.

[3] R. N. Misra, V. S. Sampath, and P. P. Bhatnagar, "Studies on silico-thermic reduction of dolomite for the production of magnesium," Trans Indian Institute of Metals, vol. 17, pp. 145154, 1961.

[4] R. N. Misra, V. S. Sampath, and P. P. Bhatnagar, Light Metal Industry in India, National Metallurgical Lab, Jamshedpur, India, 1961.

[5] 3761247,25 U.S., J. M. Avery, September,(1973).

[6] J. M. Toguri and L. M. Pidgeon, Canadian Journal of Chemistry, vol. 39, pp. 540-547, 1961.

[7] M. B. Hillert, B. Sundman, X. Wang, and T. Barry, "A reevaluation op the rankinite phase in the $\mathrm{CaO}-\mathrm{SiO}_{2}$ system," Calphad, vol. 15, no. 1, pp. 53-58, 1991.

[8] S. Kambayashi and S. E. Kato, "A thermodynamic study of (magnesium oxide + silicon dioxide) by mass spectrometry at 1973 K," The Journal of Chemical Thermodynamics, vol. 16, no. 3, pp. 241-248, 1984.

[9] F.-Z. Ji, D. Sichen, and S. Seetharaman, "Viscosities of multicomponent silicate melts at high temperatures," International Journal of Thermophysics, vol. 20, no. 1, pp. 309-323, 1999.

[10] H. C. Lin and W. R. Foster, "Stability Relations of Bredigite $\left(5 \mathrm{CaO} \cdot \mathrm{MgO} \cdot 3 \mathrm{SiO}_{2}\right)$," Journal of the American Ceramic Society, vol. 58, no. 1-2, p. 73, 1975.

[11] C. M. Schlaudt and D. M. Roy, "The Join $\mathrm{Ca}_{2} \mathrm{SiO}_{4}-\mathrm{CaMgSiO}_{4}$ , Journal of the American Ceramic Society, vol. 49, no. 8, pp. 430-432, 1966.

[12] S. N. Ghali, "A model for prediction of $\mathrm{Mg}$ content in FeSiMg alloy produced by reduction of magnesium oxide," in Proceedings of the Minerals to Materials Conference (M2M '08), p. 32, Cairo, Egypt, December 2008.

[13] H. El-Faramawy, M. Eissa, T. Mattar, A. Fathy, and S. Ghali, "Ferrosilicon magnesium production," Scandinavian Journal of Metallurgy, vol. 32, no. 1, pp. 37-46, 2003.

[14] A. Vogel, A Textbook of Quantitative Inorganic Analysis Including Elemelllary Instrumental Analysis, Woolwich Polytechnic, London, UK, 1992.

[15] L. M. Pidgeon, Transactions of the Metallurgical Society of AIME, vol. 227, pp. 821-834, 1963.

[16] K. Tomasek, I. Imris, and O. Seseiec, "Magnesium production possibilities from slovak dolomite and magnesite raw materials and wastes," in Proceedings of the Light Metals Conference, pp. 213-220, Montreal, QC, Canada, 1996. 
[17] B. Ellingstaeter and T. Rosenqvist, Journal of Metals, vol. 6, p. $111,1956$.

[18] L. M. Pidgeon and J. A. King, "The vapour pressure of magnesium in the thermal reduction of MgO by ferrosilicon," Discussions of the Faraday Society, vol. 4, pp. 197-206, 1948.

[19] J. R. Wynnyckyj and L. M. Pidgeon, "Equilibria in the silicothermic reduction of calcined dolomite," Metallurgical Transactions, vol. 2, no. 4, pp. 979-986, 1971.

[20] I. M. Morsi, K. A. El Barawy, M. B. Morsi, and S. R. AbdelGawad, "Silicothermic reduction of dolomite ore under inert atmosphere," Canadian Metallurgical Quarterly, vol. 41, no. 1, pp. 15-28, 2002.

[21] K. C. Mills and B. J. Keene, "Physicochemical properties of molten $\mathrm{CaF}_{2}$-based slags," International metals reviews, vol. 26, no. 1, pp. 21-69, 1981.

[22] R. B. Winkler, Vacuum Metallurgy, Elsevier, London, UK, 1971.

[23] W. T. Hughes, C. E. Ransky, and E. F. Emley, "Reaction kinetics in the production of magnesium by Dolomite-fer-rosilicon (Pidgeon) process," in Proceedings of the Advanced Extreme Metropolitan Proceedings, Symposium, pp. 429-454, London, UK, 1968.

[24] E. A. H. Berg, Huttemmann Monatsh, vol. 106, p. 397, 1959.

[25] R. N. Singh, Steel India, no. 7, p. 73, 1984.

[26] V. N. Potamin, S. V. Shavrim, and M.Z. Panfilov, Russ Metall, p. 63, 1976.

[27] C. W. Dannatt and H. J. T. Ellingham, "II. Roasting and reduction processes: Roasting and reduction processes-a general survey," Discussions of the Faraday Society, vol. 4, pp. 126-139, 1948.

[28] J. S. Machin and T. B. Yee, "Viscosity Studies of System $\mathrm{CaO}-\mathrm{MgO}-\mathrm{Al}_{2} \mathrm{O}_{3}-\mathrm{SiO}_{3}$ : IV, 60 and $65 \% \mathrm{SiO}_{2}$," Journal of the American Ceramic Society, vol. 37, no. 4, pp. 177-186, 1954. 

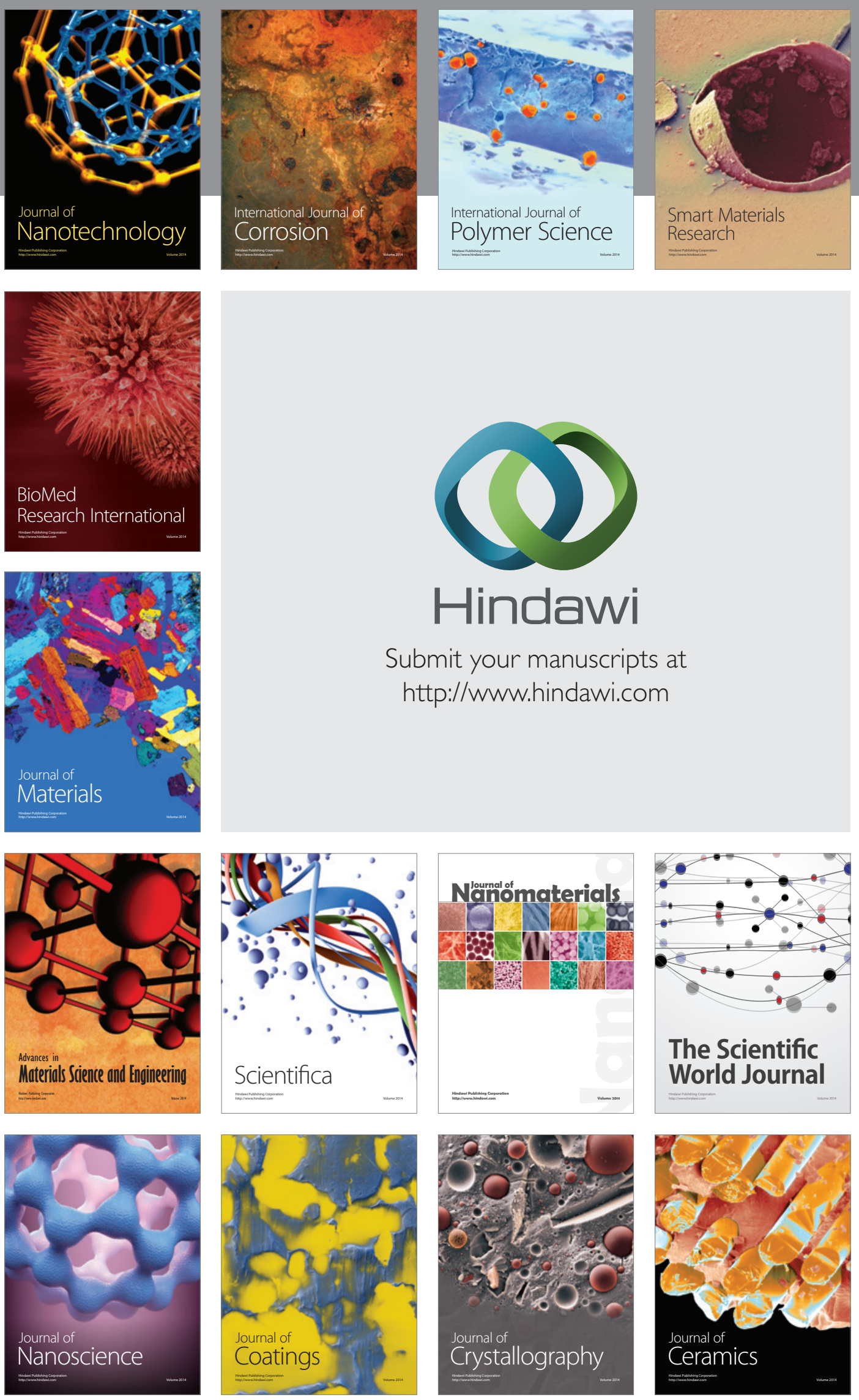

The Scientific World Journal

Submit your manuscripts at

http://www.hindawi.com

\section{World Journal}

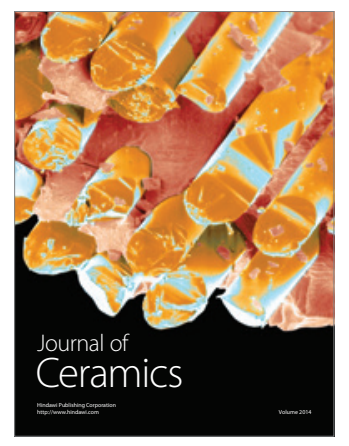

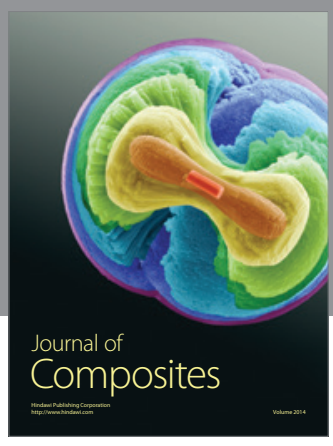
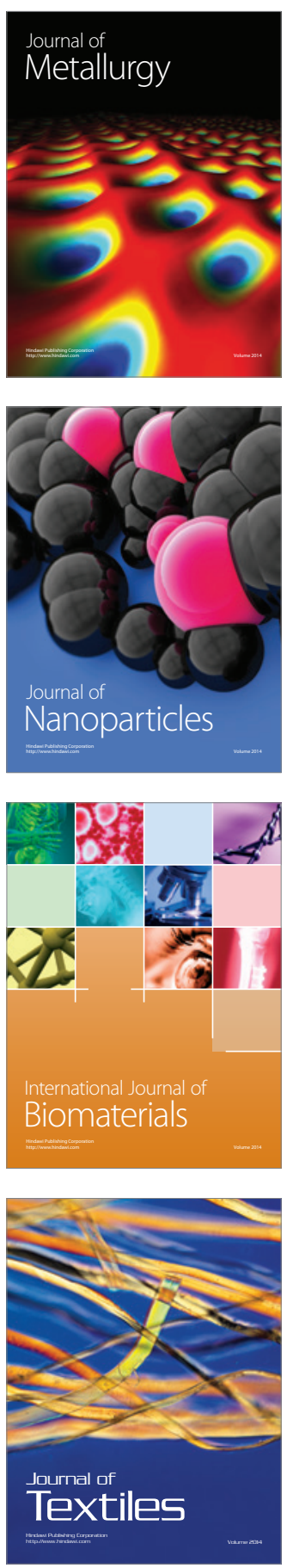